\title{
Perancangan Aplikasi Berbasis Android untuk Interaksi Juru Las Profesional dengan Kebutuhan Industri Maritim
}

\author{
Nurul Hidayati dan Heri Supomo \\ Departemen Teknik Perkapalan, Institut Teknologi Sepuluh Nopember (ITS) \\ e-mail: hsupomo@na.its.ac.id
}

\begin{abstract}
Abstrak-Setiap pembangunan konstruksi yang menggunakan material utama ferro (besi atau baja) dan juga non-ferro (aluminium, titanium, magnesium) membutuhkan penyambungan berupa pengelasan. Pekerjaan pengelasan yang dilakukan juru las biasanya dipenuhi oleh pihak ketiga yaitu sub kontraktor. Sebagai pihak ketiga, sub kontraktor biasanya tidak memiliki standar yang jelas terhadap juru las yang dipekerjakan. Belum adanya sub kontraktor yang menaungi juru las berdasarkan kemampuan kerja dan sertifikasi yang jelas mendorong adanya pembuatan sistem aplikasi labour supply juru las. Perbedaan kelas setiap juru las disebabkan oleh perbedaan pekerjaan konstruksi yang dilakukan. Tujuan utama dari penelitian studi ini adalah untuk merancang aplikasi komputer berbasis android yang digunakan untuk interaksi pengguna jasa pengelasan dan juru las. Pertama dilakukan klasifikasi dari juru las profesional. Kedua, dilakukan klasifikasi terhadap pekerjaan konstruksi yang akan dilaksanakan. Ketiga, dilakukan perancangan aplikasi komputer untuk interaksi pengguna jasa pengelasan dengan juru las menggunakan mock up sebagai alat desain awal. Terakhir, aplikasi yang sudah dirancang diujicobakan kepada beberapa responden. Aplikasi ini memiliki tiga entitas utama yaitu, akun administrator sebagai pengelola data, akun pengguna sebagai pemesan jasa pengelasan dan akun juru las. Aplikasi ini dirancang untuk mempermudah pemesanan juru las oleh pengguna jasa pengelasan melalui aplikasi android sehingga dapat menghemat waktu. Aplikasi berbasis android yang dirancang dapat membantu mempermudah pengguna jasa untuk mencari juru las yang diinginkan sesuai dengan klasifikasi pekerjaan yang akan dikerjakan. Hasil dari perhitungan investasi bisnis pengelasan berbasis aplikasi android didapatkan NPV (Net Present Value) sebesar Rp. 358.020.707,58, IRR (Internal Rate of Return) $19 \%$ dan Payback Period selama 7 tahun 9 bulan.
\end{abstract}

Kata Kunci-Aplikasi Android, Interaksi, Juru Las, Pengguna Jasa.

\section{PENDAHULUAN}

$\mathrm{P}$ EMBANGUNAN konstruksi pada bidang marine dan non marine yang menggunakan material baja diperlukan pekerjaan pengelasan di dalamnya. Teknik pengelasan bukan merupakan hal yang baru tetapi harus dilakukan dengan metode yang tepat untuk mendapatkan hasil yang maksimal dan memuaskan [1]. Setiap welder (juru las) memiliki kemampuan yang berbeda-beda. Kemampuan tersebut bisa di dapat secara otodidak atau dari pelatihan. Kemampuan kerja dari welder akan mempengaruhi biaya jasa atas pekerjaan pengelasan yang dilakukan.

Pengguna jasa welder dalam industri maritim maupun umum dari tahun ke tahun semakin meningkat. Penyalur tenaga kerja welder dalam sebuah industri maritim biasanya disebut sebagai sub kontraktor man power (pihak ketiga). Namun jasa pengelasan yang ditawarkan oleh pihak ketiga biasanya tidak memiliki kualifikasi yang jelas untuk proses pembangunan suatu kontruksi maritim sehingga seringkali pekerjaan pembangunan konstruksi menjadi terlambat. Apabila welder (juru las) memiliki kualifikasi dan sertifikasi yang jelas dan baik maka akan berpengaruh terhadap hasil pekerjaan konstruksi.

Seorang juru las terkadang juga kesulitan mencari pekerjaan apabila tidak terdaftar pada suatu perusahaan penyalur jasa pengelasan. Belum adanya sub kontraktor atau penyedia jasa yang menaungi juru las berdasarkan kemampuan kerja yang jelas mendorong penulis membuat suatu sistem model labour supply untuk juru las berbasis aplikasi android. Sistem ini nantinya diharapkan memudahkan pengguna jasa dalam mencari pekerja (juru las) sesuai dengan kualifikasi pekerjaan yang akan dilakukan. Tujuan yang dicapai dalam perancangan dan pembuatan sistem aplikasi berbasis android agar dapat menghubungkan antara industri pengguna jasa dan juru las secara cepat dan terjamin.

\section{TINJAUAN PUSTAKA}

\section{A. Pengelasan}

Pengelasan merupakan penyambungan dua bahan atau lebih yang didasarkan pada prinsip-prinsip proses difusi, sehingga terjadi penyatuan bagian bahan yang disambung. Karena proses ini maka daerah pada sekitar lasan mengalami siklus termal yang cepat [2]. Kelebihan sambungan las adalah konstruksi ringan, dapat menahan kekuatan yang tinggi, mudah pelaksanaannya, serta cukup ekonomis.

\section{1) Pengelasan Logam Ferro}

Bahan logam ferro mengandung karbon antara 0 sampai 4.5\% dan dibagi dalam 3 golongan, yaitu besi dengan kadar karbon antara 0 sampai $0.008 \%$, baja dengan kadar karbon antara $0.008 \%$ sampai $2 \%$ dan besi cor dengan kadar karbon antara $2 \%$ sampai $4.5 \%$. Besi yang digunakan dalam industri ada dua macam yaitu jenis besi tempa dan besi ingot. Besi tempa adalah besi yang mengandung terak silikat antara $2 \%$ sampai $4 \%$ sedangkan besi ingot adalah besi yang murni [3]. 2) Pengelasan Logam Non ferro

Bahan logam non ferro yang digunakan dalam pengelasan bermacam-macam, antara lain aluminium, magnesium, tembaga dan titanium. Cara untuk pengelasan masingmasing logam non ferro berbeda-beda sesuai dengan unsur paduan dalam logam non ferro tersebut. 


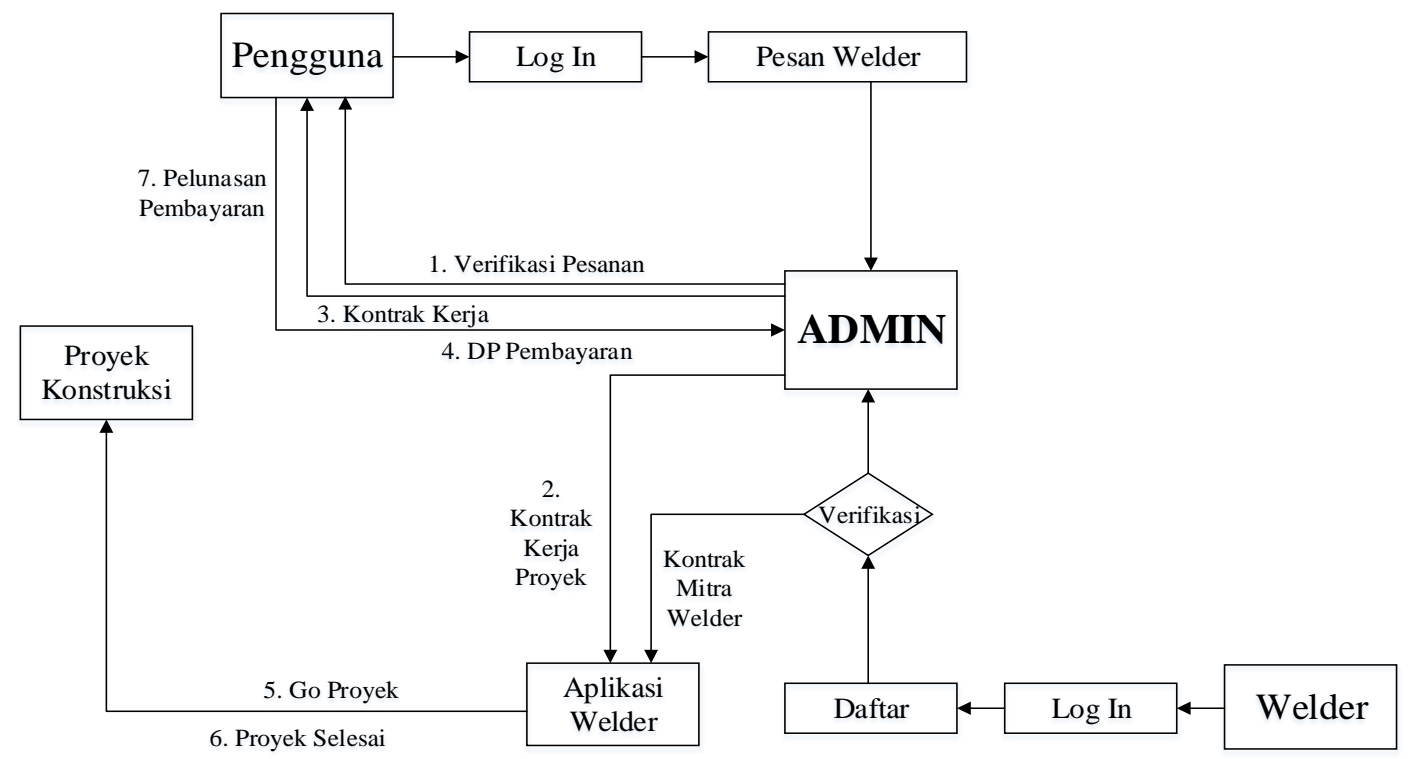

Gambar 1. Alur hubungan antar sistem pada aplikasi.

\section{B. Sertifikasi Juru Las}

Sertifikasi welder atau juru las di Indonesia biasanya dilakukan oleh LSP (Lembaga Sertifikasi Profesi). LSP ini mempunyai lisensi dari BNSP (Badan Nasional Sertifikasi Profesi). Setiap sertifikasi juru las terdapat berbagai macam jenis sertifikat yaitu berdasarkan proses atau mesin las yang digunakan saat sertifikasi dan juga posisi pengelasan yang diujikan saat proses sertifikasi berlangsung. Untuk welder marine yang mendapat sertifikasi dari BKI (Biro Klasifikasi Indonesia) maka berdasarkan peraturan BKI Volume VI Rules for Welding, setidaknya dua welder harus memenuhi kualifikasi dari BKI untuk setiap proses pengelasan pada satu pekerjaan konstruksi tertentu [4]. Juru las dapat digolongkan berdasarkan kelas, yaitu:

1. Juru Las Kelas I

2. Juru Las Kelas II

3. Juru Las Kelas III

4. Juru Las Kelas IV

\section{Industri Bisnis Konstruksi Maritim}

Pengelasan dapat diaplikasikan di berbagai tempat dan berbagai industri. Sebagai sebuah teknologi penyambungan untuk produk komersil, banyak proses pengelasan dilakukan di pabrik-pabrik. Pengelasan yang banyak digunakan pada dunia industri maritim antara lain bidang struktur bangunan laut (offshore structure) baik struktur terpancang (fixed structure) maupun struktur terapung (floating structure), struktur pipa (pipeline structure) dan proses pembangunan kapal. Hal ini menyebabkan setiap industri maritim membutuhkan kualifikasi welder yang berbeda-beda.

\section{Sistem Model Bisnis E-Commerce}

Model bisnis memberikan gambaran menyeluruh tentang cara yang dilakukan oleh sebuah perusahaan untuk menciptakan dan menentukan nilai dengan terlebih dulu menentukan empat dimensi bisnisnya, yaitu siapa, apa, bagaimana dan mengapa [5]. Model bisnis merupakan metode yang membantu perusahaan untuk bercerita mengenai kondisi internal perusahaan [6].

Osterwalder dan Pigneur mengemukakan bahwa sebuah model bisnis menggambarkan dasar pemikiran tentang bagaimana organisasi menciptakan, memberi dan menangkap nilai. Model bisnis ibarat cetak biru sebuah strategi yang diterapkan melalui struktur organisasi, proses dan sistem [7].

\section{E. Aplikasi Perangkat Lunak (Software)}

Perangkat lunak atau piranti lunak (software) adalah istilah khusus untuk data yang diformat dan disimpan secara digital, termasuk program komputer, dokumentasi, dan berbagai informasi yang bisa dibaca dan ditulis oleh komputer. Pembuatan perangkat lunak sendiri memerlukan bahasa pemrograman yang ditulis oleh seorang pemrogram (programmer) untuk selanjutnya dikompilasi dengan aplikasi kompiler sehingga menjadi kode yang bisa dikenali oleh mesin hardware.

Android adalah sistem operasi berbasis Linux yang dirancang untuk perangkat bergerak layar sentuh seperti telepon pintar dan komputer tablet. Android awalnya dikembangkan oleh Android, Inc., dengan dukungan finansial dari Google yang kemudian membelinya pada tahun 2005. Aplikasi Android berjalan di sandbox, sebuah area terisolasi yang tidak memiliki akses pada sistem, kecuali izin akses yang secara eksplisit diberikan oleh pengguna ketika memasang aplikasi.

\section{URAIAN PENELITIAN}

\section{A. Studi Literatur dan Studi Lapangan}

Studi literatur adalah teori-teori yang akan digunakan dalam menyelesaikan studi serta untuk memahami permasalahan yang sedang dibahas. Studi literatur harus relevan, aktual dan faktual dengan permasalahan yang dibahas dalam penelitian. Studi lapangan dilakukan untuk memperoleh informasi dan data yang terkait dengan penelitian yang dilakukan. Antara studi literatur dan studi lapangan harus berkesinambungan agar dapat menyelesaikan masalah yang menjadi pembahasan dalam studi. Studi literatur yang berkaitan dengan studi ini adalah :

1. Konsep dasar pengelasan

2. Perancangan sistem aplikasi berbasis android

3. Konsep dasar bisnis e-commerce. 


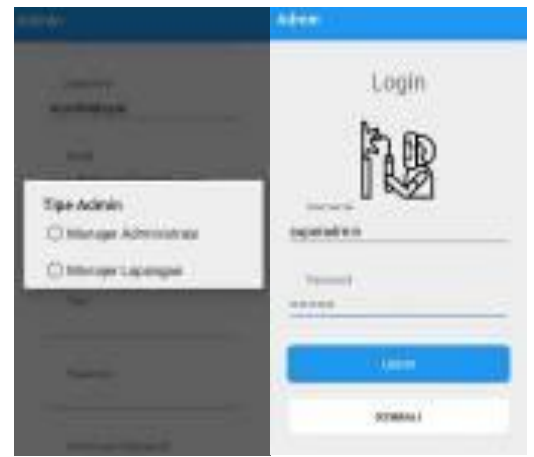

Gambar 2. Halaman pembuka administrator.

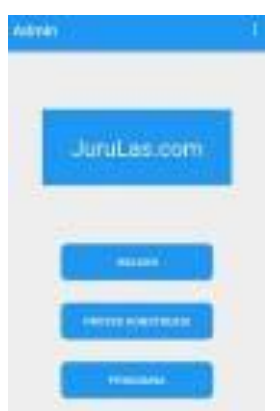

Gambar 3. Halaman menu awal.

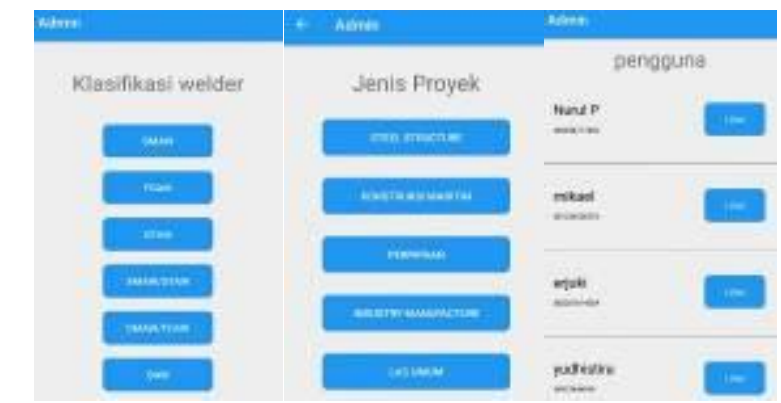

Gambar 4. Menu welder, proyek konstruksi dan pengguna

\section{B. Tahap Pengumpulan Data}

Pengumpulan data dilakukan melalui studi literatur dan studi lapangan. Data yang dikumpulkan merupakan datadata yang dijadikan dasar untuk melakukan proses perancangan aplikasi berbasis android. Data yang dikumpulkan adalah data klasifikasi juru las, data tentang pengguna jasa (industri) dan jenis pekerjaan pengelasan yang diperlukan serta data mekanisme pembuatan aplikasi berbasis android.

\section{Tahap Pengolahan Data}

Pengolahan data dilakukan dengan mengacu pada observasi yang telah dilakukan. Data-data yang telah di dapat dari berbagai sumber referensi akan digunakan untuk proses penyusunan kerangka sistem aplikasi. Mekanisme pengolahan data dalam penelitian ini sebagai berikut: (1) Pembuatan standar operasional prosedur pengelasan konstruksi; (2) Pengklasifikasian juru las profesional untuk dijadikan bahan dalam merancang sistem kelas welder; (3) Pengklasifikasian pekerjaan pengelasan dan pengguna jasa untuk dijadikan bahan merancang aplikasi user; (4) Pembuatan mock up aplikasi.

\section{Tahap Perancangan Aplikasi}

Perancangan aplikasi dilakukan melalui beberapa tahapan yaitu pemodelan aplikasi, perancangan System Interface Diagram (SID), perancangan database dan pengkodingan

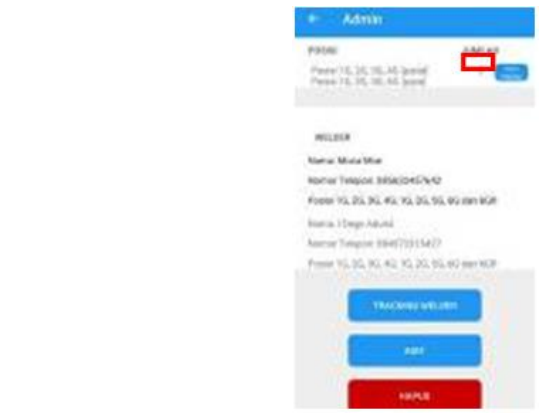

Gambar 5. Halaman menu cari welder.

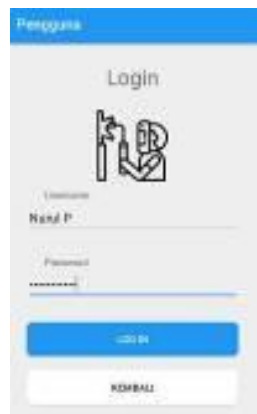

Gambar 6. Halaman pembuka aplikasi pengguna jasa.

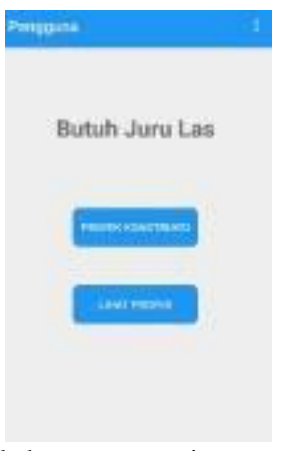

Gambar 7. Halaman awal akun pengguna jasa

aplikasi. Program aplikasi yang dibuat terbagi menjadi tiga program yang saling terintegrasi. Program tersebut adalah aplikasi berbasis android untuk pengguna jasa, aplikasi berbasis android untuk welder (juru las) dan aplikasi berbasis android untuk administrator.

\section{KONDISI KEBUTUHAN JURU LAS SAAT INI}

Seiring berkembangnya program Road Map Implementasi oleh Kementerian Perindustrian dalam industri 4.0, tenaga juru las sangat dibutuhkan. Indonesia saat ini minim sumber daya manusia untuk pengelasan dan juru las yang bersertifikasi. Ditambah kebutuhan terhadap juru las bersertifikasi cukup tinggi dan mengalami pertumbuhan positif dari tahun ke tahun seiring pertumbuhan industri yang membutuhkan produk pengelasan, mulai dari industri minyak dan gas, steel structure, industri maritim bahkan sampai industri perpipaan.

Saat ini total tenaga pengelasan di Indonesia berjumlah 15 ribu orang. Menurut Ketua Umum Indonesian Welding Engineering Society dalam kuran waktu lima tahun, Indonesia membutuhkan tenaga kerja pengelasan sebesar tiga kali lipat atau sekitar 45 ribu orang. Untuk meningkatkan pertumbuhan tenaga kerja tersebut, dibutuhkan peningkatan peralatan serta sarana dan prasarana yang memadai. 


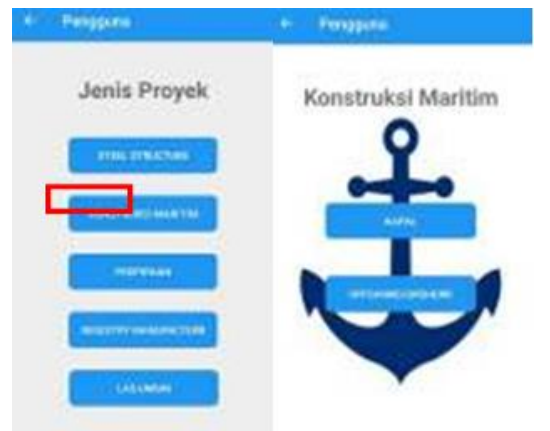

Gambar 8. Halaman Proyek Konstruksi.

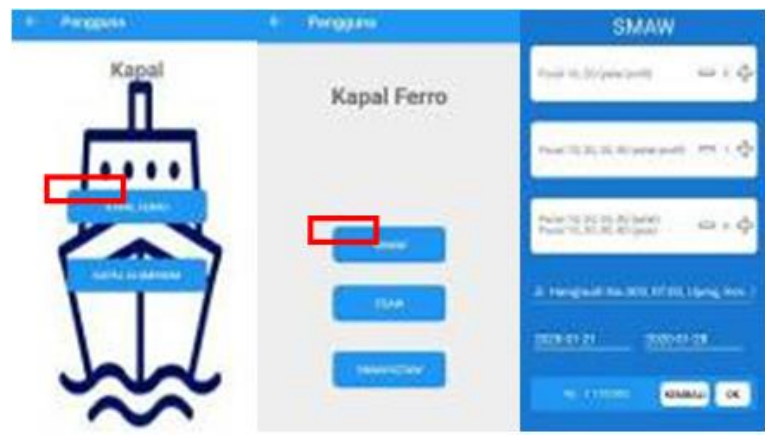

Gambar 9. Halaman pemesanan akun pengguna jasa

Segmentasi pasar dari industri adalah pembangunan kapal pada jenis dry cargo, bulkers, containers, roro ships dan tankers dengan segala ukuran. Permintaan pembangunan kapal segala ukuran diramalkan selama periode 2020-2024. Berdasarkan forecasting demand pembangunan kapal dengan rata-rata 15 kapal per tahun [8]. Dalam bidang perkapalan, proses pembangunan kapal baru perlu adanya pengawasan khusus pada setiap proses produksinya karena kapal memiliki komponen penyusun yang kompleks serta membutuhkan pengawasan dan pengecekan untuk menjamin mutu kualitas hasil pengerjaan kapal terutama pada pekerjaan pengelasan [9].

\section{PERANCANGAN PROGRAM APLIKASI}

\section{A. Pemodelan Aplikasi}

Sebelum melakukan pemodelan aplikasi, dilakukan dahulu penentuan parameter-parameter yang akan digunakan dalam aplikasi [10]. Parameter-parameter tersebut antara lain tentang klasifikasi welder berdasar proses dan posisi pengelasan serta klasifikasi pengguna jasa pengelasan. Hal ini dilakukan untuk mempermudah proses perancangan awal aplikasi. Pemodelan aplikasi dibuat dalam diagram alir (flowchart) yaitu System Interface Diagram (SID) dan alur hubungan antar sistem.

\section{B. Perancangan Aplikasi}

Perancangan aplikasi dimulai dengan pembuatan diagram interface. Perancangan diagram interface aplikasi digambarkan dengan desain mock up aplikasi. Perancangan diagram interface digunakan untuk membuat alur sistem pada aplikasi yang akan dirancang untuk memudahkan pemahaman ketika membuat mock up aplikasi. Mock up aplikasi akan digunakan sebagai dasar dalam perancangan sistem aplikasi android.

Setelah selesai pembuatan diagram interface dan mock up, tahap selanjutnya adalah pengkodingan sistem android. Pengkodingan dilakukan dengan memasukkan bahasa pemrograman menggunakan aplikasi android studio. Sesuai

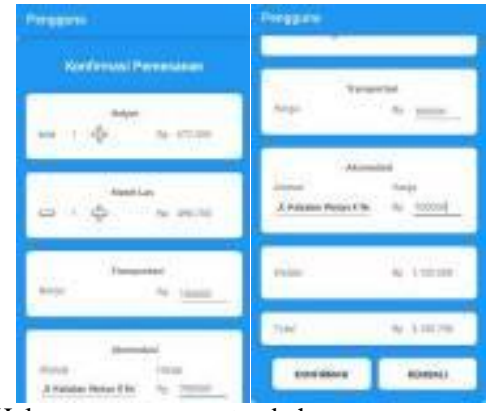

Gambar 10. Halaman pemesanan tambahan.

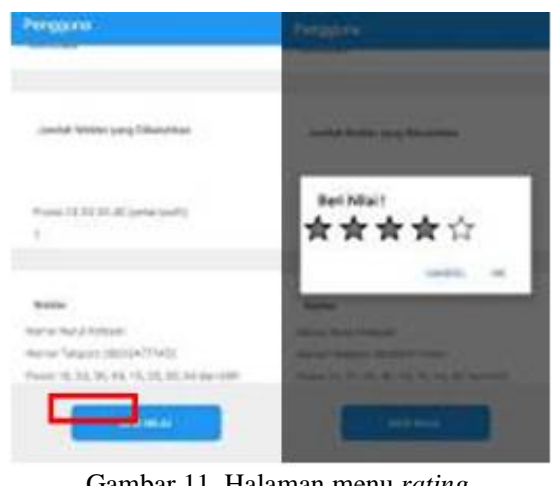

Gambar 11. Halaman menu rating.

dengan desain awal diagram interface, perancangan aplikasi berbasis android dapat dilakukan dengan lebih mudah dan sesuai dengan data dan parameter yang telah dibuat sebelumnya.

\section{Simulasi Aplikasi Pemesanan Juru Las}

Aplikasi berbasis android yang dirancang memiliki tiga entitas utama, yaitu administrator, pengguna jasa sebagai user dan welder sebagai user. Administrator merupakan pusat dari aplikasi yang dirancang. Admin dalam aplikasi ini dibagi menjadi tiga jenis yaitu, super admin (admin utama), admin administrasi dan admin lapangan. Admin memiliki kewenangan untuk memanajemen pengguna aplikasi ini, memasukkan atau mengedit data, mendaftarkan welder (juru las) dalam aplikasi, meneruskan proyek pekerjaan dari pengguna jasa ke welder, serta melakukan pengawasan terhadap aktivitas proyek yang sedang berjalan pada sistem.

1) Admin

Simulasi aplikasi pemesanan juru las untuk admin sebagai berikut :

a. Halaman Pembuka

Halaman pembuka merupakan halaman awal dari aplikasi di mana terdapat tampilan log in sesuai dengan username dan password dari akun administrator. Berikut gambar halaman pembuka dari akun administrator :

b. Halaman Menu Awal

Halaman ini terdapat tiga menu utama dari admin, yaitu menu welder, proyek konstruksi dan pengguna. Setiap menu menggambarkan fungsi utama dari admin, yaitu pengelolaan data mitra welder, pemesanan proyek konstruksi dan pengguna jasa pengelasan. Berikut gambar halaman menu utama dari akun administrator:

Menu welder untuk melihat data-data welder yang ada dalam sistem aplikasi. Welder yang melakukan pendaftaran pada aplikasi akan masuk dan terdaftar pada menu welder ini. Menu proyek konstruksi merupakan halaman untuk melihat proyek-proyek yang masuk dan sedang dikerjakan. Pada menu proyek konstruksi terdapat data lengkap pesanan welder dari pengguna jasa, mulai dari berapa welder yang 


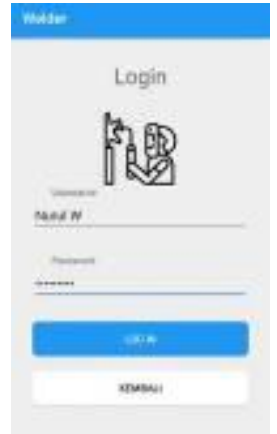

Gambar 12. Halaman pembuka aplikasi welder.

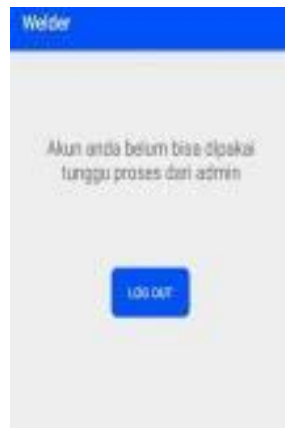

Gambar 13. Halaman verifikasi welder

dipesan, proses dan posisi pengelasan, alamat proyek dan tanggal dimulai serta berakhirnya proyek. Menu pengguna merupakan halaman dimana admin melihat siapa saja pengguna jasa yang melakukan pesanan dan masuk dalam sistem.

\section{c. Halaman Menu Cari Welder}

Halaman ini merupakan detail pesanan welder dari akun pengguna. Admin dapat melihat secara detail nama pesanan, proyek yang dipesan, kebutuhan welder serta waktu kapan proyek akan dikerjakan. Admin juga akan memilih welder yang sesuai dengan pesanan pengguna dari menu ini. Terdapat menu "cari welder" yang akan menunjukkan satu atau beberapa welder yang sesuai dengan proyek yang dipesan.

Menu tracking welder merupakan menu untuk mengetahui posisi welder melalui GPS (Global Positioning System). Admin dapat melakukan pengecekan lokasi welder yang sedang bekerja apakah sesuai dengan lokasi pekerjaan pada pemesanan.

\section{2) Pengguna Jasa sebagai User}

Pengguna jasa sebagai user adalah pengguna jasa (industri) yang melakukan pemesanan welder (juru las) berdasarkan proyek pekerjaan yang akan dilakukan. Simulasi aplikasi pemesanan juru las untuk pengguna jasa sebagai berikut :

\section{a. Halaman Pembuka}

Halaman pembuka merupakan halaman awal dari aplikasi di mana terdapat tampilan log in sesuai dengan username dan password dari akun pengguna jasa.

b. Halaman Awal/Utama

Setelah pengguna berhasil log in, terdapat menu pilihan untuk proyek konstruksi dan lihat proyek.

Menu proyek konstruksi digunakan untuk memilih juru las yang akan dipesan berdasarkan pilihan proyek konstruksi yang tersedia. Menu lihat proyek merupakan histori pemesanan oleh pengguna jasa.

\section{c. Halaman Proyek Konstruksi}

Halaman ini merupakan halaman menu proyek konstruksi dimana akan muncul pilihan proyek yang ditawarkan dalam

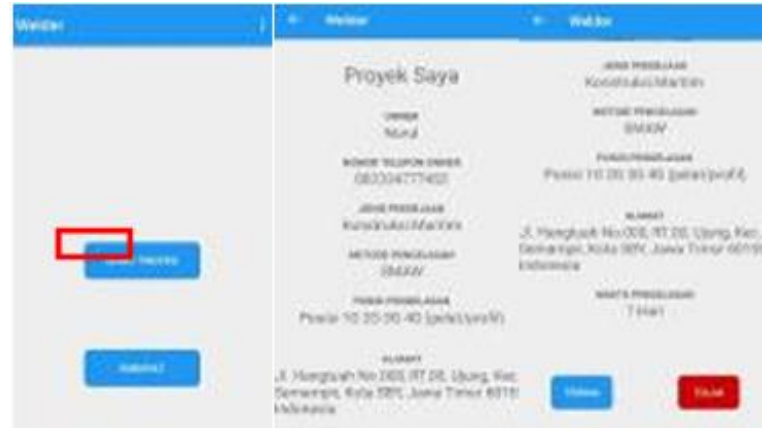

Gambar 14. Halaman utama akun welder.

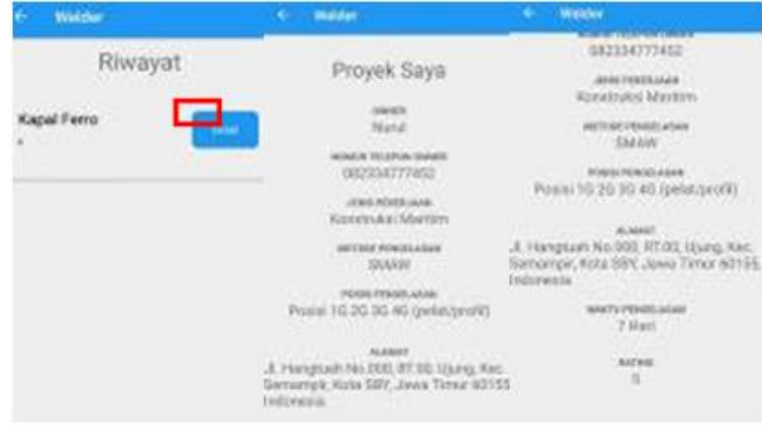

Gambar 15. Halaman riwayat akun welder.

aplikasi. Terdapat lima pilihan proyek yang dapat dipilih, yaitu steel structure, konstruksi maritim, perpipaan, industry manufacture dan pengelasan umum.

Halaman konstruksi maritim muncul ketika pada halaman jenis proyek/proyek konstruksi user memilih menu konstruksi maritim. Terdapat dua macam pekerjaan kontsruksi pengelasan yaitu kapal dan offshore/onshore.

d. Halaman Pemesanan Welder

Pada halaman pemesanan, pengguna jasa dapat memilih berapa welder yang akan dipesan, proses pengelasan dan posisi pengelasan yang akan dikerjakan.

e. Halaman Pemesanan Tambahan

Pada halaman pemesanan tambahan, pengguna jasa dapat memilih tambahan pemesanan helper, mesin las, transportasi dan akomodasi.

f. Halaman Menu Rating

Halaman rating merupakan halaman dimana pengguna dapat memberikan nilai atas pekerjaan yang juru las telah kerjakan. Menu rating ini terdapat dalam menu "Lihat Proyek" seperti pada Gambar 7.

3) Welder sebagai User

Welder sebagai user adalah welder (juru las) yang akan menerima pekerjaan pengelasan dari pengguna jasa (industri) yang telah melakukan pemesanan welder berdasarkan proyek pekerjaan yang akan dibangun. Welder berhak menerima pekerjaan sesuai dengan kemampuan dan data spesifikasi mereka yang telah ada dalam daftar akun administrator. Simulasi aplikasi pemesanan juru las untuk welder sebagai berikut :

a. Halaman Pembuka

Halaman pembuka merupakan halaman awal dari aplikasi di mana terdapat tampilan log in sesuai dengan username dan password dari akun welder.

b. Halaman Verifikasi

Setelah welder berhasil $\log$ in, terdapat halaman menu verifikasi oleh admin. Jika admin belum melakukan verifikasi maka tampilan dari aplikasi welder tidak akan dapat diakses dan welder tidak akan dapat menerima proyek pengelasan. 


\section{c. Halaman Utama Welder}

Halaman ini akan muncul setelah welder mendapat accepted dari admin. Halaman utama welder merupakan halaman dimana welder dapat melihat proyek konstruksi yang diberikan oleh admin. Berdasarkan perjanjian mitra yang telah disepakati maka welder diwajibkan untuk menerima dan melaksanakan pesanan yang diberikan oleh admin baik melalui aplikasi android, call centre atau yang diatur oleh perusahaan.

d. Halaman Riwayat

Halaman Riwayat merupakan halaman dimana histori dari pekerjaan proyek yang pernah dikerjakan oleh welder. Pada halaman ini welder dapat melihat sudah pernah mengerjakan proyek apa saja dan berapa nilai yang telah diberikan oleh pengguna jasa.

\section{ANALISIS SISTEM APLIKASI}

Aplikasi pemesanan juru las berbasis android memiliki kelebihan dan kekurangan, antara lain sebagai berikut :

\section{A. Kelebihan}

a. Membantu dalam pemesanan juru las profesional secara online melalui aplikasi android. Pengguna jasa pengelasan yang membutuhkan juru las untuk proses pengerjaan konstruksi dapat melakukan pemesanan welder via aplikasi android tanpa harus mencari subkon untuk manpower.

b. Melalui aplikasi android pengguna jasa dapat dengan mudah memenuhi kebutuhan juru las tanpa harus bertemu atau bertatap langsung dengan pihak penyalur juru las.

c. Pemesanan jasa pengelasan dapat dengan mudah diproses oleh admin sehingga proses pemesanan juru las via aplikasi dapat lebih cepat berlangsung.

d. Sertifikasi dan kualifikasi juru las berbagai proses dan posisi pada sistem aplikasi membuat pengguna jasa bebas memilih juru las sesuai dengan kebutuhan pekerjaan konstruksi yang akan dikerjakan.

e. Harga juru las yang relatif normal, tidak berdasarkan sedikit banyaknya proyek pengelasan yang biasanya membuat harga jasa juru las melambung tinggi.

\section{B. Kekurangan}

a. Sistem pembayaran tidak dapat dilakukan diawal proyek, pihak admin harus mengcover biaya jasa dari juru las terlebih dahulu sebelum dilakukan pembayaran oleh pihak pengguna. Pembayaran juga belum dapat dilakukan dalam sistem aplikasi.

b. Pekerjaan pengelasan yang diambil welder saat offline dari aplikasi dan diluar ketentuan pemesanan. Selama pekerjaan tidak berhubungan dengan pemesanan sebelumnya (misal pemesanan yang melebihi tanggal pada aplikasi) dan selama welder menerima dan melaksanakan pesanan dari admin maka tidak masalah jika mengambil pekerjaan pengelasan diluar aplikasi.

c. Verifikasi pemesanan dari admin ke pengguna dilakukan via email, belum dapat masuk pada sistem aplikasi android.

d. Tampilan dari aplikasi masih bersifat monoton dan belum menarik

\section{KESIMPULAN}

Aplikasi sistem android yang dirancang terdiri dari dua entitas utama yaitu administrator (management office) dan user (pengguna jasa dan juru las). Administrator memiliki kewenangan menerima atau menolak pesanan juru las yang masuk, melihat progres pekerjaan, accepted welder yang masuk sistem, edit/hapus data, dan juga accepted admin yang daftar. Aplikasi yang dirancang dapat menghubungkan pihak industri (pengguna jasa) dengan juru las secara cepat dan terjamin.

Aplikasi ini memiliki kelebihan kecepatan proses pemesanan tenaga juru las dengan spesifikasi dan kualifikasi yang terjamin dan dengan harga jasa yang relatif stabil dikarenakan juru las dalam sistem yang tidak akan mempermainkan harga.

Nilai rata-rata tertinggi pada kuesioner tentang fungsi aplikasi berbasis android yang dapat membantu dalam pemesanan juru las sebesar 3,6. Nilai rata-rata terendah didapatkan pada pertanyaan tentang tampilan dari aplikasi yang kurang menarik dengan nilai rata-rata 2,6. Meski tampilan pada aplikasi memiliki nilai rata-rata terendah tetapi masih masuk dalam range ke tiga (baik). Dari total rata-rata nilai yang telah diolah didapatkan nilai rata-rata sebesar 3,19, yang masuk pada range ke tiga (baik). Ini berarti bahwa aplikasi berbasis android untuk pemesanan juru las disarankan untuk diaplikasikan.

Nilai investasi dari bisnis pengelasan dikatakan layak dengan nilai NPV lebih dari nol yaitu sebesar sebesar Rp. 358,020,707.58, nilai IRR sebesar 19\% (lebih dari nilai bunga bank sebesar 11\%) dan Payback Period selama 7 tahun 9 bulan (tidak melebihi waktu pengembalian investasi).

\section{DAFTAR PUSTAKA}

[1] M. S. Azdkar, H. Pratikno, and H. S. Titah, "Analisis pengelasan SMAW pada baja ASTM A36 dengan variasi elektroda terhadap sifat mekanik dan ketahanan biokorosi di lingkungan laut," J. Tek. ITS, vol. 7, no. 2, pp. G180-G185, 2018.

[2] S. D. Anggraeni, H. Pratikno, and Y. S. Hadiwidodo, "Studi perbandingan proses pengelasan pada lingkungan darat dan bawah terhadap ketahanan uji bending weld joint material A36," J. Tek. ITS vol. 5, no. 2, pp. G236-G241, 2016.

[3] H. Wiryosumarto and T. Okumura, "Teknologi pengelasan logam," Pradya Paramita, 2000.

[4] Biro Klasifikasi Indonesia, Rules for The Classification and Construction, Volume VI: Rules for welding. Jakarta: Biro Klasifikasi Indonesia, 2015

[5] O. Gassmann, K. Frankenberger, and M. Csik, Business Model Navigator: 55 Model Bisnis yang akan Mengubah Bisnis Anda. Jakarta, Indonesia: Elex Media Komputindo, 2016.

[6] M. Rainaldo, B. M. Wibawa, and Y. Rahmawati, "Analisis Business Model Canvas pada pperator jasa online ride-sharing (Studi kasus Uber di Indonesia)," J. Sains dan Seni ITS, vol. 6, no. 2, pp. D232D236, 2017.

[7] A. Osterwalder and Y. Pigneur, Business Model Generation: A Handbook For Visionaries, Game Changers, and Challengers. New York: John Wiley \& Sons, 2010.

[8] S. Pratama, "Analisis Teknis dan Ekonomis Pembangunan Industri Model Akomodasi untuk Kapal Niaga dalam Rangka Meningkatkan TKDN," Institut Teknologi Sepuluh Nopember, 2019.

[9] R. Achmafajri and T. W. Pribadi, "Perancangan aplikasi berbasis android untuk pemeriksaan pengelasan pada bangunan kapal baru," $J$. Tek. ITS, vol. 6, no. 1, pp. G1-G7, 2017.

[10] R. R. Putra and T. W. Pribadi, "Perancangan aplikasi berbasis android untuk proses manajemen mutu pada pembangunan kapal baru," $J$. Tek. ITS, vol. 5, no. 2, pp. G129-G135, 2016. 